\title{
Adoption of Multiple Sustainable Land Management Practices among Irrigator Rural Farm Households of Ethiopia
}

\author{
Rahel Deribe Bekele ${ }^{1}$, Alisher Mirzabaev ${ }^{2}$, and Dawit Mekonnen ${ }^{3}$ \\ ${ }^{1}$ University of Bonn, Center for Development Research \\ ${ }^{2}$ University of Bonn \\ ${ }^{3}$ International Food Policy Research Institute
}

February 18, 2021

\begin{abstract}
Using a household and plot-level survey conducted in 2016/17 in ten districts of Ethiopia, this study explores whether there is a difference in farmers' adoption of sustainable land management (SLM) practices between their rainfed and irrigated plots. The paper also investigates the varying influence of different types of irrigation water management systems and associated irrigation technologies on the adoption of SLM practices in irrigated plots. Our findings show only a small difference in the average number of SLM practices between rainfed and irrigated plots, even though significant differences are observed between many of the practices applied individually among these plots. The econometric estimation shows that the role of the combined effect of irrigation water management system and irrigation technology on adoption of SLM practices is quite varied and very significant. The evidence highlights that farmers adopt more SLM practices in their plots with pump irrigation compared to those plots where gravity irrigation is applied. This finding implies that pump irrigation systems enhance complementarities with SLM practices. Furthermore, the results indicate that the type of irrigation water management and the technology applied could play an important role in restoring degraded lands and maintaining soil fertility, even when farmers' adoption of irrigation were not explicitly triggered by concerns for soil health.
\end{abstract}

\section{Hosted file}

Main text_Adoption of Multiple Sustainable Land Management Practices_2.pdf available at https://authorea. com/users/396557/articles/509710-adoption-of-multiple-sustainable-landmanagement-practices-among-irrigator-rural-farm-households-of-ethiopia 